UDK 81 '33

DOI 10.20535/2617-5339.2019.4.181340

\author{
Miguel Ángel Candel-Mora \\ PhD in Linguistics, Assistant Professor \\ Department of Applied Linguistics \\ Universitat Politècnica de València \\ Valencia, Spain \\ ORCID ID 0000-0001-8754-6046 \\ mcandel@upv.es
}

\title{
INTERCULTURAL COMMUNICATION COMPETENCE IN SPECIALIZED LANGUAGES AND CONTEXTS: RESEARCH PROSPECTS AND POSSIBILITIES
}

\begin{abstract}
Recent advances in communication technologies, globalization, internet 2.0, mobile communication and social networks, among many other factors, have led to a growth of possibilities of communication between people of different languages and cultures never seen before in the history of the world. However, recent language research highlights the fact that knowledge of the language alone does not guarantee successful communication in international contexts: cultural diversity, intercultural communication competence, cultural intelligence, intercultural sensitivity and intercultural awareness place an emphasis on the intercultural dimension of foreign language education. It is stated that foreign language training in professional settings needs to be customized according to the academic context, social demands and professional profiles of individuals. Existing intercultural communication competence assessment instruments seem to focus on generic needs of learners, based on a generic learning context, and measure the individual's ability to communicate in a foreign language across cultural boundaries, but at the same time, seem to pay attention to the variable of a specialized context biased by cultural constrains. It seems that universal intercultural communication competence assessment models are failing to meet actual requirements and training efforts are not aligned with teaching objectives. Upon identifying the basic dimensions of intercultural communication such as knowledge, attitude and behaviour, this study proposes a revision of different specialized communication settings and intercultural communication competence instruments from the perspective of professional communication and then review existing research lines to, finally, propose research opportunities from the point of view of specialized languages and contexts.
\end{abstract}

Keywords: English as a lingua franca; specialized languages; foreign language education; intercultural communication competence; intercultural communication competence assessment.

\section{INTRODUCTION}

In recent years, the influence of communications technologies, especially mobile communications, globalization, the active participation of users in Internet 2.0 and social networks have led to an unprecedented increase in communication possibilities between people of different languages and cultures never seen before (Fantini, 2009).

In this context, the increase in the use of English as a lingua franca is justified to facilitate communication between people from different countries and cultures that would otherwise require knowledge of more than one foreign language to interact. However, language teaching research highlights the fact that knowledge of a language alone does not guarantee effective communication in international settings. Hence, there is an increase of research initiatives on cultural diversity, intercultural communication competence (ICC), cultural intelligence, intercultural sensitivity and intercultural awareness that stand out in foreign language teaching (Zaharna, 2009; Committee for Economic Development, 2006).

A review of the literature on intercultural communication competence assessment reveals an emphasis on the approach to the generic needs of learners, according to generic contexts, to measure the individual's ability to communicate in a foreign language internationally (Byram, 1997, p. 7; Fritz, Möllenberg, \& Chen 2002, p. 166), however they do not seem to pay attention to communication in specialized contexts biased by cultural constrains. Therefore, everything seems to indicate that most ICC assessment models fail to fully meet the current demand, in addition to not 
considering that the teaching objectives need to be aligned with training efforts.

From the point of view of language teaching in professional settings, it is necessary to take into consideration aspects such as the academic context, social demand and professional profiles of students, similar to what is done during the design of specialized language courses by means of needs analysis (Candel-Mora, 2015).

Therefore, based on preliminary considerations such as the fact that culture is closely associated with language, that ICC studies propose universal tools in generic environments, and the role of English as a language for knowledge exchange at an international level, this work promotes further research in ICC in specialized contexts and questions the effectiveness of ICC tools valid for all cultures and languages, and encourages the consideration of non-native to non-native interactions in the design of assessment tools. According to Planken et al. (2004), SL learners are likely to use their foreign language with non-native speakers of different nationalities.

Thus, upon describing the characteristics of specialized languages and their professional and academic environments, this article reviews the literature on the basic dimensions of intercultural communication, such as knowledge, attitudes and behaviour, and highlights some of the instruments that consider intercultural communication in specialized communication environments. Then, it proposes a content analysis of some of the most relevant publications of the last five years on intercultural communication to identify research opportunities adapted to the context of teaching specialized languages.

\section{METHODS}

The research exploited the theoretical analysis of scholarly sources with the following synthesis and generalization.

\section{THEORETICAL BACKGROUND}

The relationship between the need to include ICC assessment in specialized languages (LSP) teaching lies in the trend towards globalization and internationalization and the need to be competent in professional settings with people from different cultural contexts. From the higher education perspective, the Bologna and EHEA objectives place special emphasis on the promotion of mobility from the early stages of future professionals' training (Leuven and Louvain-la-Neuve Communiqué, 2009), which reveals a research field open to possibilities in combining ICC and LSP.

Although the characterisation of LSP has not clear boundaries, the field of LSP teaching has a long trajectory of research and study. The debate started with the determining whether special languages are independent systems of the general language or not. In this sense, Cabré (1993, p. 132134) classifies the different positions of the most representative authors and identifies three main areas: LSP forms an autonomous system within the set of the general language; LSP are lexical variants of the general language; and, LSP are subsets, mainly pragmatic of a global language.

According to Cabré (1993, p. 135), several elements are shared by the general and specialized language, which allows to reach a consensus and a more detailed definition of LSP: they deal with a specific topic, are used in a given area, and also by a certain type of users; have interrelated characteristics, and should not therefore be regarded as isolated phenomena; the communicative function prevails over other complementary functions.

Research on LSP uses methods and techniques from different disciplines. Hoffmamn (1998, p. 21-69) proposed seven methodological guidelines for its analysis and description: lexical and terminological orientation; functional linguistics orientation; the business linguistics orientation; the functional stylistics orientation; philosophical orientation; translation orientation; and, orientation based on the theory of sublanguages.

This brief review of the main guidelines that have been followed for the study of LSP allows concluding that the two main axes of the study of LSP are based, on the one hand, on the observation and analysis of the terminological aspects that characterize this type of language; and, on the other hand, on the study of more communicative and functional aspects.

All in all, LSP share a common set of core criteria: 
1. Language is considered as an instrumental vehicle, subject to a more general goal

2. Teaching is organized around some type of needs analysis

3. Each course is designed specifically for a certain group of students

Overall, the primary objective is to bridge the knowledge of foreign language learners who already know the specific scientific-technical characteristics of their context, and then transfer their general learning strategies to develop communicative competence so that they can function in their academic environment in the first instance and in their professional lives later.

\subsection{Intercultural communication competence}

The definition of intercultural competence has also attracted the attention of scholarly debates over the past decades (Shuang Liu, 2012, p. 270) since conceptualizations of ICC are highly diverse in their disciplines, terminologies, and practical objectives (Committee for Economic Development, 2006, p. 4). Terms such as intercultural competence, intercultural effectiveness, and intercultural adaptation largely trace back to the 1970s.

Fantini (2009, p. 456) confirms the lack of consensus among writers and researchers and identifies at least twenty terms to refer to intercultural studies such as biculturalism, multiculturalism, communicative competence, cross-cultural adaptation, cultural competence, intercultural sensitivity, international communication, intercultural interaction, among others.

Given the complexity of assessing intercultural competence, according to Deardorff (2009, p. 403): "it is important to use a multimethod, multiperspective approach when assessing intercultural competence". Thus, this study concentrates on intercultural communicative competence, which differs from intercultural competence in the fact that ICC is carried out in a language that is not one's mother tongue. For this reason, although many of the methods used in intercultural communication studies are adopted from other disciplines such as intercultural communication, language and linguistics, applied linguistics, TESOL, education, discourse studies, translation studies, communication studies, language learning and teaching, gender studies, we will focus on language learning methods to define the application of ICC in LSP teaching.

There are different definitions of ICC depending on the approach adopted. Byram $(1997$, p. 7) states that it is "an individual's ability to communicate and interact across cultural boundaries", while others such as Fritz, Möllenberg and Chen (2002, p.166) focus on the ability to develop a positive attitude towards the foreign culture.

This work goes a step beyond and analyses ICC from the perspective of intercultural communication in English between non-native speakers, an added difficulty, since knowledge of the language does not imply knowledge of a culture, or as Zaharna (2009, p. 190) puts is: "it is possible to be fluent in the language yet ignorant of the culture", especially between individuals who communicate in a lingua franca that is not their native tongue.

At first sight the most common lingua franca context variables are: different accents, different pragmatic expectations, and different discoursal patterns, however "people tend to be less forgiving of social gaffs from a linguistically competent individual than they are of linguistic gaffs from a culturally competent individual" (Zaharna, 2009, p. 190).

\subsection{ICC Assessment tools}

The usual method to assess the competence of an individual is by means of ICC assessment tools, however, in this specialized context it is difficult to find a single tool that adequately assesses intercultural learning and it is necessary to adopt a multi-perspective approach that takes into account the dimensions most commonly cited in the literature. Authors such as Chen and Starosta (1996) identify three dimensions: intercultural awareness, intercultural sensitivity, and intercultural adroitness; others like Spitzberg and Chagnon (2009) adopt a more cognitive approach and distinguish between cognitive dimension, affective dimension and behavioural dimension. From the perspective of psychology and communication, Arasaratnam and Doerfel (2005) identify four dimensions: empathy, experience, motivation, positive attitude towards other cultures, and listening. However, in the field of language teaching, object of this study, we will focus on Byram's 
proposal (1994) of three dimensions: knowledge, attitudes and behaviour, especially because it applies directly to foreign language education.

Byram (1994) defines the Knowledge dimension as the factual knowledge such as historical and geographical facts. The Attitudes dimension refers to the encouragement of positive attitudes towards language learning and towards people from other countries and communities. Finally, Behaviour is taken from its broadest sense, not only limited to notions of politeness, etiquette and social niceties.

Given the multidisciplinary nature of ICC, the number of existing ICC assessment tools is so wide that the simple listing of available tools would exceed the scope of this work. Some instruments value linguistic aspects, others, cultural aspects, others the combination of both. The Intercultural Communication Institute (http://www.intercultural.org/tools.php) supports the impossibility of using a single tool, and suggests some such as Cross-Cultural Adaptability Inventory, Intercultural Sensitivity Inventory, Discovering Diversity Profile, The Global Competencies Inventory or, Diversity Awareness Profile, along with links to other assessment tools repositories and guidelines to choose the combination of tools that best suits the users' needs.

Among the main characteristics of tools are, their purpose: determine preparedness for an intercultural experience, compatibility with specific cultural contexts or one's disposition toward a specific culture; target audience: students, job candidates or international professionals; background: business or research; and aspects evaluated: language level or job placement. With regards to the assessment format, tools use surveys, questionnaires or interviews with closed and open-ended questions, matching items, true / false questions, multiple-choice questions, role-plays, and simulations, corpus analysis or conversation analysis.

In the case of LSP teaching, concepts such as intercultural teams, international meetings, geographical mobility, worldwide negotiations, and globalization to name just a few are intrinsically associated to the professional profiles of graduates and reveal the need to include ICC contents in their foreign language courses syllabi.

\section{RESULTS AND DISCUSSION: CONTENT ANALYSIS OF ICC IN LSP CONTEXTS}

Despite the maturity of ICC research from the perspective of language teaching, in the field of LSP there are few studies that bring together both disciplines. The methodology followed in this work consisted in selecting four of the most relevant academic journals in intercultural communication research (Journal of Intercultural Communication Research, Language \& Intercultural Communication, Journal of International and Intercultural Communication, and International Journal of Intercultural Relations) and after compiling published articles in the last five years, a total of 1,032 articles, carry out a content analysis to identify the most frequent lines of research, and identify those that bring together the study of intercultural communication from the perspective of professional and specialized environments. The method used, inductive content analysis, has been chosen because of the potential to identify patterns and reduce large amounts of text to obtain relevant information.

At first glance, the titles of the articles reveal five axes around which the research revolves: the focus of the research, the dimension of the ICC studied, the group studied, and the languages and nationalities involved, in addition to the methodology of research used.

From a total of 2,862 keywords from the titles of the articles, the analysis was carried out with the 400 words with the highest frequency of occurrence in the corpus. Those that appeared at least 5 times in the database of titles were selected, however, in some of the classifications; keywords with a lower rate of occurrence were included precisely to highlight the limited research on the subject.

The first axis, the focus of the research, reveals ten repetitive patterns on which the article is developed: language, education, professional, culture, social, mobility, gender, race, political, religion. Language and education, with 437 and 365 occurrences respectively, are the most common, far from the rest. The rest of research topics range from 85 appearances of "professional" to 6 - "religion". The most common languages in research in order of importance are English, Chinese, Japanese and Korean. 
In the case of the ICC dimension studied, 267 references were found that specifically included related keywords such as "identity", "attitudes", "adaptation", "adjustment", "identities", "prejudice", "perceptions", "understanding", "values", "knowledge", “awareness", "perspectives", "integration", "stereotypes", being "behavior" the least mentioned in the studies, with 10 cases.

The range of targeted individuals is also very diverse: teachers, immigrants, youth, students, adolescents, workers, expatriates, migrants, refugees, highlighting the educational and professional environment and the attempt to integrate research into the early stages of training as revealed by the appearance of "youth", "students" and "adolescents" in 43 articles.

The category of country/nationalities studied is also significant since the main focus seems to be towards distant cultures, with greater potential to contain cultural characteristics quite different from the West, where most of the research takes place, such as China, Korea, Japan and Asia. However, the comparison is made mostly with the United States and Europe.

Likewise, the Language category with 437 occurrences highlights the languages of the countries mentioned in the previous category: Chinese, Japanese, Korean, although the majority is English, to which most comparative studies are carried out. Other languages identified in the database are Russian, Spanish, Turkish, French, Norwegian, and Finnish, with Arabic with less research incidence, 2 articles.

\section{CONCLUSIONS AND SCOPE FOR FURTHER RESEARCH}

This work shows that intercultural competence is a longitudinal and ongoing developmental process since it is not only carried out in early stages of education but also in professional settings.

It is clear that intercultural competence is a complex area of study and that the most successful way of conducting research requires its fragmentation into measurable items that shed light on specific dimensions such as knowledge, attitude or skill areas.

Since knowledge of the language alone is not a guarantee of success in an international professional environment, further research is needed on a proposal for an ICC assessment model that emphasizes the intercultural communication component from the beginning of LSP training. Especially, after the analysis of the database of more than one thousand references which has identified scarce references to intercultural communication in LSP in the last 5 years.

\section{REFERENCES}

Arasaratnam, L. A., \& Doerfel, M. L. (2005). Intercultural communication competence: Identifying key components from multicultural perspectives. International Journal of Intercultural Relations, 29, 137-163. DOI: http:// dx.doi.org/10.1016/j.ijintrel.2004.04.001

Byram, M., et al. (1994). Teaching and Learning Language and Culture. Clevedon: Multilingual Matters.

Byram, M. (1997). Teaching and Assessing Intercultural Communicative Competence. Clevedon: Multilingual Matters. Cabré, M. T. (1993). La terminología. Teoría, metodología, aplicaciones. Barcelona: Editorial Antártida/Empúries.

Candel-Mora, M. Á. (2015a). Attitudes towards Intercultural Communicative Competence of English for Specific Purposes Students. Procedia - Social and Behavioral Sciences, 178, 26-31. DOI: http://dx.doi.org/10.1016/j. sbspro.2015.03.141.

Candel-Mora, M. Á. (2015b). Benchmarking intercultural communication competence assessment tools for ESP teaching. ELIA, 15, 93-107. DOI: http://dx.doi.org/10.12795/elia.2015.i15.05.

Committee for Economic Development Research and Policy Committee. (2006). Education for global leadership: The importance of international studies and foreign language education for U.S. economic and national security. Washington, DC: Committee for Economic Development.

Deardorff, D. K. (2006). Identification and Assessment of Intercultural Competence as a Student Outcome of Internationalization. Journal of Studies in International Education, 10, 241-266. DOI http://dx.doi. org/10.1177/1028315306287002

Deardorff, D. K. (2009). Implementing Intercultural Competence Assessment. In D. K. Deardorff (Ed.), The SAGE Handbook of Intercultural Competence (pp. 477-491). Thousand Oaks, CA: Sage.

Fantini, A. (2009). Assessing Intercultural Competence: Issues and Tools. In D. K. Deardorff (Ed.), The SAGE Handbook of Intercultural Competence (pp. 456-476). Thousand Oaks: SAGE Publications.

Fritz, W., Möllenberg, A., \& Chen, G. (2002). Measuring Intercultural Sensitivity in Different Cultural Contexts. Intercultural Communication Studies, 11, 2.

Hoffmann, L. (1998). Llenguatges d'especialitat. Barcelona: IULA, Universidad Pompeu Fabra. 
Intercultural Communication Institute. (2015). Intercultural Training and Assessment Tools. Portland: Intercultural Communication Institute. Retrieved on 01.03.2019 from http://www. intercultural.org/tools.php

Leuven and Louvain-la-Neuve Communiqué. (2009). The Bologna Process 2020: The European Higher Education Area in the new decade. Commmunique of the Conference of European Ministers Responsible for Higher Education. Belgium. Retrieved on 05.04.2015 from http://www.ehea. info/Uploads/Declarations/Leuven_Louvain-la- Neuve_Communique_April_2009.pdf

Planken, B., van Hoofl, A., \& Korzilius, H. (2004). Promoting Intercultural communicative competence through foreign language courses. Business Communication Quarterly, 67(3), 308-315.

Shuang, L. (2012). Rethinking intercultural competence: Global and local nexus, Journal of Multicultural Discourses, 7, 269-275. DOI: http://dx.doi.org/10.10 80/17447143.2012.693085.

Spitzberg, B. H., \& Changnon, G. (2009). Conceptualizing intercultural competence. In D. K. Deardorff (Ed.), The Sage Handbook of Intercultural Competence (pp. 2-52). Thousand Oaks: SAGE Publications.

Zaharna, R. S. (2009). An Associative Approach to Intercultural Communication Competence in the Arab World. In D. K. Deardorff (Ed.), The SAGE Handbook of Intercultural Competence (pp. 179-195). Thousand Oaks: SAGE Publications.

Мігель Ангель Кандель-Мора. Міжкультурна комунікативна компетентність у спеціалізованих мовах і контекстах: перспективи та можливості досліджень. Автор указує, що останні досягнення в галузі комунікаційних технологій, Інтернету 2.0, мобільного зв'язку та соціальних мереж тощо призвели до зростання небачених раніше в історії людства можливостей спілкування між людьми різних культур. У статті наголошено, що знання іноземної мови саме по собі не гарантує успішне спілкування в міжнародних контекстах. Тут важливого значення набуває формування міжкультурної комунікативної компетентності, яка передбачає вміння співпереживати й уважно слухати, ефективно спілкуватися з представниками інших культур, бути поступливим у взаєминах, відчувати бажання до пізнання нового, характерного іншим культурам. Міжкультурна комунікативна компетентність стосується набуття нового знання з досвіду спілкування й уміння розуміти погляди інших людей. Окреслено міжкультурну комунікативну компетентність як інструмент досягнення успіху в міжкультурній взаємодії та якісному виконанні своїх професійних обов'язків. Зазначено, що навчання іноземної мови професійного спрямування має відбуватися в академічному контексті відповідно до соціальних вимог та обраного фаху. Наголошено, що сучасні інструменти оцінювання міжкультурної комунікативної компетентності мають вимірювати здатність студентів спілкуватися іноземною мовою у кроскультурному контексті. Але сьогодні вони не відповідають вимогам та нерідко не узгоджуються 3 навчальними цілями. Автор, визначаючи основні виміри міжкультурної комунікативної комунікації (знання, цінності, ставлення та поведінка), в цьому дослідженні пропонує переглянути різні спеціалізовані комунікативні стратегії та інструменти оцінювання міжкультурної комунікативної компетентності з точки зору професійного спілкування, а також існуючі наукові напрями у цій сфері задля дослідницьких можливостей з точки зору спеціалізованих мов та різних контекстів.

Ключові слова: англійська мова як лінгва франка; спеціалізовані мови; іншомовна освіта; міжкультурна комунікативна компетентність; оцінювання міжкультурної комунікативної компетентності. 